\title{
Effect of Monetary Policy on the Nigerian Stock Market: A Smooth Transition Autoregressive Approach
}

\author{
Jamilu S. Babangida ${ }^{1}$ and Asad-UI I. Khan ${ }^{2}$
}

This paper examines the nonlinear effect of monetary policy decisions on the performance of the Nigerian Stock Exchange market, by employing the Smooth Transition Autoregressive (STAR) model on monthly data from 2013 M4 to $2019 \mathrm{M12}$ for All Share Index and monetary policy instrument. This study considers the two regimes characterizing the stock market, which are the lower regime (the bear market) and the upper regime (the bull market). The results show evidence of nonlinear effect of monetary policy on the stock exchange market. Monetary policy rate, money supply, lagged monetary policy rate and lagged treasury bill rate are found to have significant positive effects on the stock exchange market in the lower regime while current treasury bill rate shows a negative effect. In the upper regime, money supply and lagged treasury bill rate have significant negative effect on the stock market. The current treasury bill rate is found to have a positive effect on the stock exchange market. It is recommended that the Central Bank of Nigeria should maintain a stable money supply growth that is consistent with increased activities in the Nigerian stock market.

Keywords: Monetary policy, nonlinear, smooth transition autoregressive model, stock prices JEL Classification: C58, D53, E52, E58, G10

DOI: $10.33429 /$ Cjas.12121.1/6

\subsection{Introduction}

Globally, the stock market of any economy plays the important role of mobilizing domestic resources for productive investments. The stock market is regarded as an integral component of most economies, since it signals redistribution, and reallocation of assets among different economic units within an economy (Pilinkus, 2010). The performance of this market is tied to the overall performance of an economy. Particularly, the growth in the Nigerian economy in the last two decades can be associated with the impact of stock market on the overall economy (Bertram, 2018; Ifionu \& Omojefe, 2013). This is to say that the evolution of the economy is fundamentally connected with the capital market performance. Thus, research on monetary policy and stock exchange market has become an issue of discourse among policy

\footnotetext{
${ }^{1}$ Ahmadu Bello University, Zaria \& Ibn Haldun University, Turkey and Corresponding Author: jsbabangida@gmail.com

${ }^{2}$ Ibn Haldun University, Turkey:asad.khan@ihu.edu.tr
} 
makers. In view of this development, the monetary policy tools are adjusted and aimed at achieving the macroeconomic goals of inflation and output targets as well as control any risk or threat to financial system stability (Echekoba, Ananwude, \& Lateef, 2018). Evidently, the Central Bank of Nigeria (CBN) has interest in the overall workings of the stock market due to its importance for monetary policy and financial risk management. This is because the Bank has the ability to impact on the capital market via interest rate, credit, wealth effect, exchange rate and monetary channels (Mishkin, 2016; Nwakoby \& Alajekwe, 2016).

The literature showing the relationship between monetary policy and the stock market is unclear both in direction and nature of behaviour. Bulk of the existing literature on the behavior between stock market and monetary policy assumed a linear relationship (Muktadir-Al-Mukit \& Shafiullah, 2012; Chude \& Chude, 2013; Handoyo, Jusoh, \& Zaidi, 2015; Echekoba, Okaro, Ananwude, \& Akuesodo, 2017; Echekoba et al., 2018; and Umezurike \& Ananwude, 2019). Another strand of studies have shown that a comprehensive explanation of the relationship between monetary policy and stock exchange market goes beyond assuming a linear behaviour (McMillan, 2001; Sarantis, 2001; Aslanidis, Osborn, \& Sensier, 2002; Cevik, Dibooglu, \& Kutan, 2014; Tumala \& Yaya, 2015; and Altintas \& Yacouba, 2018). Most studies revealed the existence of nonlinearity in assessing the relationship between monetary policy and stock market. Assuming linearity might give a misleading and systematic bias in the relationship because of central banks' diverse response to shocks from the stock market and vice versa. As a result, a nonlinear approach is suitable to show the relationship between monetary policy and stock exchange market. Ma (2016) argued that nonlinearity results from either "asymmetry in central banks' preferences and nonlinearities in the macroeconomic structure of an economy" as well as the different responses to abrupt changes or shocks in policy and stock exchange market by individual risk averse agents in the market. This reveals that the nonlinear behaviour of stock market performance towards monetary policy instrument is underpinned by numerous theoretical and empirical literature.

This study is motivated by the unsettled debate and recent literature that document the crucial importance of monetary policy transmission to the stock market using linear models. We ask and assess whether a nonlinear model can account for the well documented response of stock market to monetary policy. Specifically, this paper attempts to investigate the impact of monetary policy decisions on the stock market. Firstly, the study examines the asymmetric 
impact of monetary policy on stock market performance using the nonlinear smooth transition autoregressive (STAR) model for the Nigerian economy. This contributes to existing empirical literature and offers understanding into stock market asymmetric behaviour in a developing country like Nigeria using a robust methodology. Secondly, as revealed by $\mathrm{Al}$ Mukit and Shafiullah (2012) and Belke and Beckmann (2015), the interaction between stock prices and the monetary policy process could be reversed. Therefore, the study tests a linear and nonlinear causality between stock exchange market and monetary policy in Nigeria.

The remaining part of the paper is structured thus: Section 2 presents the review of literature; Section 3 comprises data and methodology; Section 4 presents and discusses the results; and finally, Section 5 presents the conclusions and policy recommendations.

\subsection{Literature Review}

\subsection{Theoretical Framework}

Mishkin (2016) asserted that the impact of monetary policy on stock market performance is based on some important conditions: that return on bonds is expected to decline if interest rate is reduced by the Central Bank. Consequentially, this leads investors agreeing to a lower rate of return on an investment in equity as an alternative asset. This resulting fall in the required rate of return would increase the value of stock. Moreover, dividends would likely rise because of a decrease in interest rates. The constant-growth dividend discount model or the Gordon discount model depicts that an increase in the growth rate of dividend also leads to a rise in stock prices through its effect on decreasing denominator. This values a company's stock without taking into consideration some market conditions which could increase the value of a company.

On the other hand, the discounted cash flow model offers another useful insight on the relationship between stock market and monetary policy instruments. According to this model, the present value of expected future dividends is assumed to be the discounted cash flow. This indicates that any change in monetary policy can influence stocks in two ways: Firstly, through direct effect of adjustment of discount rate of market participants under the assumption that discount factors are generally linked to market rates of interest as well as the monetary authorities' ability to influence the rate of interest using any of its instruments. A system of tight monetary policy rule has effect on future cash flow via the rate of interest, making the value of stock to fall (Chatziantoniou, Duffy \& Filis, 2013). Secondly, changes in monetary 
policy indirectly affect the value of a firm's stock through its weight on the expected returns. Monetary policy expansion is expected to raise the overall level of economic activity which has a positive effect on the stock market.

This study employs the discounted cash flow model as its theoretical framework where the All-share index, monetary policy rate, treasury bill rate and money supply are used to proxy the stock market and monetary policy instruments.

\subsection{Empirical Literature}

Examining the relationship between interest rate and stock market capitalization, Ologunde et al. (2006) found that interest rate has a positive impact on stock market capitalization and a negative effect on government development stock rate. In the same view, Osisanwo and Atanda (2012) revealed that interest rate, past stock return levels, money supply and exchange rate are the main factors explaining the behavior of stock returns in Nigeria. Nwakoby and Alajekwe (2016) found evidence in support of Chude and Chude (2013); that there exist a long run interaction between monetary policy and stock market performance in Nigeria. This indicates that monetary policy considerably explains the variations in stock market performance. The study also showed evidence of causal relationship from stock market performance to monetary policy implying that monetary policies adjust to stock market activities. In another study on 12 African countries, Suhaibu, Harvey, and Amidu (2017) established that stock markets are positively affected contemporaneously by monetary policies through the interest rate channel. The study also found an evidence of reverse causality from stock markets to monetary policy. This is established by the fact that both money supply and real interest rate falls due to positive and negative stock market shocks. This finding is supported by Umezurike and Ananwude (2019), who established the presence of an inverse linkage between monetary policy rate and value of stock traded in Nigeria. The study asserted that monetary policy rate propels real economic activity which translates to affect the behaviour of the stock market. Additional findings showed that a higher monetary policy rate results in high lending rate causing security prices to be volatile and investment in capital market less attractive.

In light of the significant effect of monetary policy on stock market performance, Okpara (2010) showed that monetary policy is a major determinant of long-run stock market returns in Nigeria. Interest rate was also found to have a positive and significant influence on stock 
market returns. However, Echekoba et al. (2018) found contrary evidence that monetary policy has insignificant impact on capital market in Nigeria. However, the Granger causality test result revealed a causal relationship from stock market to monetary policy rate. Using panel data, Ioannidis and Kontonikas (2008) investigated the impact of monetary policy on stock returns for some selected OECD countries. The study showed that changes in monetary policy transmits to the stock market because of the strong negative response of the stock market to interest rates. In line with the findings of Abouwafia and Chambers (2015), that monetary tightening led to a collapse in stock prices in the Middle East countries with varying dynamics and magnitudes, Singh and Nadkarni (2018) suggested that stock returns are generally higher in expansionary monetary environment and that monetary tightening result to a decline in stock prices with different dynamics and magnitude.

Using structural vector autoregressive (SVAR) methodology for US monetary policy and S \& P 500, Bjrnland and Leitemo (2009) found strong interdependence between interest rate and stock prices. This suggests that a positive stock price shock leads to increase in interest rate. Afroze (2013) examined the impact of monetary policy on the performance of Dhaka stock exchange from 2006 to 2010. The study found a significant correlation among the indicators for measuring money supply and performance of Dhaka stock exchange. Using data from the same stock exchange market, Muktadir-Al-Mukit and Shafiullah (2012) investigated the response of post crashed Dhaka stock market of 1996 to monetary policy. The study revealed that a volatile monetary policy has a negative relationship with stock exchange market index. From the Granger causality test results, inflation and money supply were found to cause changes in Dhaka stock exchange index. Studying the effect of monetary policy changes on the Chinese monetary and stock markets, Tang, Luo, Xiong, Zhao, and Zhang (2013) found that monetary market is related to the macroeconomic trend and the monetary changes of expansion and contraction surprises that impact on the two markets in different manner. Shanghai stock market index responds to these monetary changes and that the stock market digests the monetary policy changes slowly.

In a more comprehensive study, Handoyo et al. (2015) provided evidence that not only is monetary policy able to influence the stock prices in Indonesia, but also the interaction between monetary and fiscal policy. In an extended paper examining the dynamic linkages between monetary policy and stock market under three distinct monetary regimes in the US 
(that is, Burns, Volcker and Greenspan), Laopodis (2013) found that asset prices were sensitive to changes in monetary policy. The impact of monetary policy on nominal stock returns was shown to be more pronounced in the pre- and Volcker periods but dissipates fast afterwards. In addition, the result showed the presence of asymmetric responses of the stock market as a result of the Fed's policies during bull and bear markets.

Several studies on the linkage between monetary policy and stock market adopted a linear framework. However, other researchers have done a great deal on these linkages using a nonlinear framework. For instance, Sarantis (2001) employed the smooth transition autoregressive (STAR) model on stock returns of G7 countries, and found a slow transition asymmetry between regimes. McMillan (2001) also found evidence of a nonlinear relationship between stock market returns and macroeconomic and financial variables in the U.S. Using a two regime STAR model. Interest rate was found to be the most important determinant in the two regimes. Similarly, Aslanidis et al. (2002) revealed that the nonlinear behaviour of U.K. stock returns is driven by the dividend yield and the U.S. stock returns. Similarly, Hyde and Bredin (2011) using the STAR model for the U.S., Ireland, Japan, U.K, Belgium, Canada, France and Germany found evidence of nonlinearity in all countries. In the linear regime, interest rates and exchange rates were found to be significant determinants of stock returns. Accounting for nonlinearity in the model, interest rate and inflation were the significant determinants of stock returns in these countries. Using data for Nigeria, Tumala and Yaya (2015) estimated the bull and bear betas of the stock market by employing the logistic STAR (LSTAR) model. The study found evidence of varying betas for the two markets with a fast transition across portfolios in the markets. This implies various risk/return characteristics of equities under the two different regimes.

Some studies utilized other forms of nonlinear models to examine the asymmetric linkage between the variables. For instance, using Markov switching model to identify bull and bear markets, Gacener, Atis and Erer (2018) analyzed the asymmetric response of stock market returns and volatility to monetary policy in Turkey over the period of 2002:1-2016:12. The study found that monetary policy rate does not have significant effect on stock market return in both bull and bear market periods in the short run. Conversely, in the long run, the study found that monetary policy rates positively influence stock market volatility in bull and bear markets, however, the effect is higher in bull market period than bear market. In other words, 
monetary policy is more effective in bull market periods.

Examining the relationship between Bogota stock returns and the Colombia interbank loan interest rate, Arango, González, and Posada (2002) found evidence of nonlinear and negative effect of interest rate on the stock prices of Colombia, though, the impact is small. Using data for Turkish economy, Altintas and Yacouba (2018) investigated the asymmetric response of stock market prices to oil prices and money supply shocks using a nonlinear autoregressive lag (NARDL) approach. The study showed that stock prices asymmetrically respond to money supply changes in the short and long run. This indicated that irrespective of positive or negative shocks occurring in money supply, stock market prices rise. The findings also suggest asymmetric long run response of Turkish stock market prices to global oil prices confirming the importance of nonlinearity in macro-finance variables.

The evidence reviewed here suggest a pertinent role for monetary policy on stock exchange market. These studies clearly indicate that there is a linkage between monetary policy and the stock exchange market. In view of reviewed studies for Nigeria, one may suppose that there is a universal linear behavior for examining the relationship until the study by Tumala and Yaya (2015) that offers an alternative way of studying the stock market asymmetries. From the foregoing, it can be observed that existing studies linking monetary policy and stock market behaviour in Nigeria adopted a linear framework with few studies utilizing the nonlinear framework. Evidence from existing literature provides a strong justification for nonlinear specification and estimation in order to give a comprehensive information about the relationship. In light of these reviewed studies, there exists a gap in estimating the relationship between monetary policy and the Nigerian Stock Exchange market using a nonlinear method.

\subsection{Data and Methodology}

\subsection{Data}

This study utilized monthly data to examine the effect of monetary policy on the Nigerian stock market. The Nigerian stock exchange market's proxy is the All Share Index (Q) collected from Yahoo Finance database. Monetary policy rate (MPR), 91-day treasury bill rate (TBR) as a measure of short-term interest rate, broad money supply (M2) and exchange rate (EXR) are considered as the monetary policy instruments, while inflation (INF) is used as a control variable. Data for these variables covering the period from 2013M4 to 2019M12 
were collected from various editions of CBN annual report.

\subsection{Model Specification}

The constant growth, discounted cash flow theory and the existing empirical studies for both developed and developing economies underpin the specification of the interaction between monetary policy and stock market ( Muktadir-Al-Mukit \& Shafiullah, 2012; Chude \& Chude, 2013; Handoyo, Jusoh, \& Zaidi, 2015; Echekoba, Okaro, Ananwude, \& Akuesodo, 2017; Echekoba et al., 2018; Umezurike \& Ananwude, 2019). In examining the relationship between stock exchange market and the monetary policy in Nigeria, the study begins with the specification of a functional model adapted from Nwakoby and Alajekwe (2016). The functional relationship is stated thus:

$$
Q_{t}=f\left(Z_{t}\right)
$$

where $Q_{t}$ represents all share index at time $\mathrm{t}$ and $Z_{t}$ represents the monetary policy rate at time $t$ and the control variables at time $t$. The model can be specified in an extensive form prior to the STAR specification and estimation as in (2).

$$
Q_{t}=\alpha_{t}+\beta M P R_{t}+\varphi M 2_{t}+\theta T B R_{t}+\phi E X R_{t}+\psi I N F_{t}+\varepsilon_{t}
$$

where $\alpha, \beta, \varphi, \theta, \phi$ and $\psi$ are the coefficients of the variables in the study as previously defined and $\varepsilon_{t}$ is the error term which is assumed to be iid $\left(0, \delta^{2}\right)$. The choice of MPR and money supply as monetary policy instruments stem from the importance of the rate and money in the dicounted cash flow model and the fact that most studies have used these as monetary policy instruments which has direct effect on financial variables like the stock prices (see, Jansen \& Tsai, 2010; Laopodis, 2013; Thorbecke, 1997; Altintas \& Yacouba, 2018). Based on other empirical studies and the country's characteristic of using foreign exchange intervention as a complementary tool for liquidity management, exchange rate was included. Inflation (INF) was also added as a control variable in the model.

\subsection{Estimation Procedure}

This study utilizes a STAR model in line with Teräsvirta (1998) intuitive three-step methodology for estimation in a multivariate context. ${ }^{3} \quad$ As argued in Petersen (2007), the STAR

\footnotetext{
${ }^{3}$ These steps are (i) set up a linear model forming the starting point for analysis, choose transition variable and decide between LSTAR or ESTAR; (ii) find suitable starting values for the nonlinear estimation; (iii) evaluate the model by various test misspecification.
} 
model has the capability to assess and analyze the rationale for central bank's policy rule adjustment. The model differs from linear models because it establishes nonlinear relationship and examines the asymmetric effects of monetary policy and the stock market. Unlike other nonlinear models, as noted by Teräsvirta (1994) the STAR model assumes a smooth switch from one regime to another because economic agents respond differently to shocks. Moreover, the STAR model nests both linear and nonlinear components within a single framework. The STAR models allows different types of market behavior depending on the form that the transition function takes (McMillan, 2003). In line with extant literature, the empirical model is specified as:

$$
y_{t}=\beta_{1}^{\prime} w_{t}+\left(\varphi_{0}+\varphi_{1}^{\prime} w_{t}\right) G\left(s_{t-d}\right)+\varepsilon_{t}
$$

where: $w_{t}=\left(z_{t}^{\prime}, x_{t}^{\prime}\right)^{\prime}$ is an $(m+1) \times 1$ vector with $z^{\prime}=\left(1, y_{t-1}, \ldots, y_{t-p}\right)^{\prime}$ and $x_{t}^{\prime}=\left(x_{t}, \ldots, x_{k t}\right)^{\prime}$, $\mathrm{m}$ is the number of explanatory variables. $\beta$ and $\varphi$ are the parameter vectors of the linear and nonlinear parts, respectively. $\varepsilon_{t}$ is iid $\left(0, \delta^{2}\right)$; and $G\left(s_{t-d}\right)$ is a transition function and dis the delay parameter. If it does follow a logistic STAR process, the transition function would be of this form:

$$
G\left(s_{t-d}\right)=\left[1+\exp \left(-\gamma\left(s_{t-d}-c\right)^{-1}\right)\right] \quad \gamma>0
$$

On the other hand, if it does follow an exponential STAR process, the transition function would take this form:

$$
G\left(s_{t-d}\right)=\left[1-\exp \left(-\gamma\left(s_{t-d}-c\right)\right)\right]^{2} \quad \gamma>0
$$

The transition function $G\left(s_{t} ; \gamma, c\right)$ defining the regime depends on the transition variable $s_{t}$, the slope parameter $\gamma$ which determines the speed of the transition, and the vector of the location parameter $c$, which represents the threshold for regime switching or represents the half way point between two distinct regimes (Sarantis, 2001); that is, bull and bear in this study. The transition variables $s_{t}$ can be part of $z_{t}$ or it can be another variable like trend. The transition function $G\left(s_{t} ; \gamma, c\right)$ is bounded between 0 and $l$ where extreme values represent two different regimes with gradual transition. The STAR model requires that a transition variable must be identified with a threshold value (where a change from a low regime to a high regime takes place $)^{4}(\mathrm{Ma}, 2016)$. The STAR modelling procedure has three stages from

\footnotetext{
${ }^{4}$ The regimes represent bear and bull markets.
} 
specifying, selecting to estimating the model. Firstly, the STAR specifies and estimates a nested linear AR model; where $\gamma \rightarrow 0$, the model becomes a linear AR. Secondly, linearity is tested against nonlinearity (STAR) model for different values of the transition variable using the linear AR model specified with a null of linear relationship (See, Teräsvirta, 1994; Teräsvirta \& Anderson, 1992). Thirdly, after confirming nonlinearity by rejecting linearity, a test is carried out on the following auxiliary model

$$
y_{t}=\beta_{1}^{\prime} w_{t}+\beta_{2}^{\prime} w_{t} s_{t-d}+\beta_{3}^{\prime} w_{t} s_{t-d}^{2}+\beta_{4}^{\prime} w_{t} s_{t-d}^{3}+\varepsilon_{t}
$$

The test can be used to check, whether there is nonlinearity of the STAR type in the model. This auxilliary regression has a null hypothesis of linearity against the alternative of nonlinearity. The null hypothesis of linearity is $H_{0}: \beta_{2}^{\prime}=\beta_{3}^{\prime}=\beta_{4}^{\prime}=0$. This linear restriction is checked by applying an F test. It is denoted in the output with the F symbol. The test for the two variants of the STAR model is based on the same auxiliary regression (6) as the linearity test. Furthermore, a test is to be carried out on two transition functions (i.e. LSTAR or ESTAR) to identify the appropriate model for the study. Following Terasvirta (1994), we could select between ESTAR or LSTAR by conducting a series of tests within (3). The justification behind this sequence is based on interpreting the coefficients which determine the parameters of the STAR model in (3), with either (4) or (5). Correspondingly, LSTAR and ESTAR are selected based on the F-statistics of the null hypothesis. The study is deciding based on the null hypothesis $H_{04}: \beta_{4}=0 ; H_{03}: \beta_{3}=0 / \beta_{4}=0$; and $H_{02}: \beta_{2}=0 / \beta_{3}=\beta_{4}=0$. The selection of logistic STAR implies the rejection of the null hypothesis of $H_{03}$. Rejecting $H_{03}$ after accepting $H_{02}$ implies the choice of LSTAR. For an ESTAR model, the situation may be expected to be the opposite. After rejecting the general null hypothesis, carry out the three $\mathrm{F}$ tests. If the $\mathrm{p}$ value of $\mathrm{F} 3$ (the test of $\mathrm{H}_{02}$ ) is the smallest of the three, select an ESTAR model; if not, choose a LSTAR model (Teräsvirta, 1994). The validity and reliability of the estimated models are checked by applying a battery of diagnostic tests. ${ }^{5}$.

The granger causality test is carried out within both linear and nonlinear framework. The test would be performed on the STAR-based model.

$$
y_{t}=\beta_{1}^{\prime} w_{t}+\left(\varphi_{0}+\varphi_{1}^{\prime} w_{t}\right) G\left(s_{t-d}\right)+\delta_{1}^{\prime} z_{t}+\left(\delta_{20}+\delta_{2}^{\prime} z_{t}\right) F\left(y_{t-e}\right)+\varepsilon_{t}
$$

where $y_{t}$ is the causing variable, $z_{t}=\left(y_{t-1}, \ldots y_{t-q}\right)^{\prime}, \boldsymbol{\delta}_{j}=\left(\boldsymbol{\delta}_{j 1}, \ldots, \boldsymbol{\delta}_{j q}\right)^{\prime}, \mathbf{j}=1,2$,

\footnotetext{
${ }^{5}$ autocorrelation, additional nonlinearity, and parameter constancy.
} 
$\mathrm{F}($.$) is a transition function, and \mathrm{e}$ is the delay parameter. Other variables are as earlier defined.

The null hypothesis of the granger causality test is $H_{0}=\delta_{1}^{\prime}=\delta_{20}^{\prime}=\delta_{2}^{\prime}=0$. However, the null hypothesis of the model 7 is not identified. Skalin and Teräsvirta proposed the Taylor series expansion of the transition function ( Sarantis, 2001).

\subsection{Results and Discussion}

\subsection{Descriptive Statistics}

Table 1. Descriptive Statistics

\begin{tabular}{lllllll}
\hline & Q & TBR & MPR & M2 & INF & EXR \\
\hline Mean & 25.9621 & 10.4168 & 13.0741 & $2.14 \mathrm{E}+07$ & 11.7091 & 244.8188 \\
Median & 20.4610 & 10.8000 & 13.5000 & $2.19 \mathrm{E}+07$ & 11.2400 & 305.1800 \\
Maximum & 50.6009 & 14.9300 & 14.0000 & $2.85 \mathrm{E}+07$ & 18.7200 & 309.7300 \\
Minimum & 6.3053 & 0.0000 & 11.0000 & $1.43 \mathrm{E}+07$ & 7.7000 & 158.0200 \\
Std. Dev. & 13.2184 & 2.8319 & 0.9556 & $4.02 \mathrm{E}+06$ & 3.4580 & 65.2203 \\
Skewness & 0.7794 & -1.5502 & -0.5480 & 0.0604 & 0.6272 & -0.1874 \\
Kurtosis & 2.0735 & 6.2960 & 1.9499 & 2.0202 & 2.0504 & 1.1641 \\
Jarque-Bera & 11.0969 & 69.1062 & 7.7749 & 3.2894 & 8.3540 & 11.8500 \\
Probability & 0.0039 & 0.0000 & 0.0205 & 0.1931 & 0.0153 & 0.0027 \\
Sum & 2102.93 & 843.760 & 1059.00 & $1.73 \mathrm{E}+09$ & 948.44 & 19830.32 \\
Sum Sq. Dev. & 13977.98 & 641.57 & 73.06 & $1.30 \mathrm{E}+15$ & 956.60 & $3.4 \mathrm{E}+05$ \\
Observations & 81 & 81 & 81 & 81 & 81 & 81 \\
\hline
\end{tabular}

Table 1 presents the summary statistics of the data. The coefficient of skewness indicates that all the variables, except TBR are near zero. Data for MPR, EXR and TBR are skewed left while Q, M2 and INF are skewed right. The kurtosis coefficients of the variables range from 1.2 to 6.3 which reflects a leptokurtic distribution for only TBR. This implies that the data is characterised by the presence of outliers. The probability value for Jacque-Berra suggest that only M2 is normally distributed among the variables. Except for M2, all other variables exhibit no standard normality features. This suggest that the variables are suitable for the modelling approach.

\subsection{Pre-estimation Tests}

The variables in this study were tested for unit root using the Augmented Dickey Fuller (ADF) and Phillips-Perron (PP) approaches. The stationarity condition of the variables is important to avoid the problem of spurious result due to explosive data. The results are presented on Table 2. 
Effect of Monetary Policy on the Nigerian Stock Market:

Table 2. Unit Root Test

\begin{tabular}{|c|c|c|c|c|c|}
\hline \multirow[t]{2}{*}{ Variables } & \multicolumn{2}{|c|}{$\mathrm{ADF}$} & \multicolumn{2}{|c|}{ PP } & \multirow[t]{2}{*}{ Remarks } \\
\hline & Level & 1st Difference & Level & 1st Difference & \\
\hline $\mathrm{Q}$ & -1.64 & $-11.94 * * *$ & -1.43 & $-13.06 * * *$ & $\mathrm{I}(1)$ \\
\hline TBR & $-6.72 * * *$ & - & $-6.67 * * *$ & 一 & $\mathrm{I}(0)$ \\
\hline MPR & -1.85 & $-8.80 * * *$ & -1.89 & $-8.80 * * *$ & $\mathrm{I}(1)$ \\
\hline M2 & -0.19 & $-10.37 * * *$ & -0.04 & $-10.38 * * *$ & $\mathrm{I}(1)$ \\
\hline INF & -1.75 & $-3.24 * * *$ & -1.35 & $-4.09 * * *$ & $\mathrm{I}(1)$ \\
\hline EXR & -1.02 & $-6.20 * * *$ & -1.04 & $-4.41 * * *$ & $\mathrm{I}(1)$ \\
\hline
\end{tabular}

Based on the critical values, both ADF and PP tests suggest that except for TBR, which is stationary at level, all the other variables are stationary after differencing once.

\subsection{Linearity vs Nonlinearity Tests}

This study used an iterative procedure to estimate the model to arrive at the optimal lag length. The model with the lowest AIC or BIC is selected Teräsvirta, 2004). Firstly, we estimate the model by considering a lag length of 8 . Then, the optimum lag length of one (1) is reached based on AIC and SIC information criteria. Upon selecting the lag order of the model, the tests for linearity and the selection of STAR models are estimated. Table 3 presents the tests of linearity against nonlinearity. Except for present and lagged value of MPR, the null hypothesis of linearity in the model was rejected for TBR, M2 and EXR. This suggests a nonlinear model explaining the behaviour between the selected variables and the stock exchange market during the time of study. The results further suggest a linear model for the linkage between Monetary policy rate and the stock exchange market in Nigeria. It is interesting to note, however, that exchange rate is revealed to be the transition variable for this study based on the highly significant F-value among the other nonlinear models. Therefore, the study adopts a STAR model after the hypothesis of linearity is rejected. The version of the STAR (i.e., LSTAR and ESTAR) models are selected based on the lowest p-values of the test reported in Table 3.

The tests reveal the relationship is an exponential variant of STAR with the selection of exchange rate driving the transition. This implies that the relationship between monetary policy decision and the stock exchange market in Nigeria has differing behaviour resulting from large and small trades in the market. We proceed by conducting a grid search over $Z_{t}, c 1, c 2, \gamma$ to select the starting values for the slope coefficient and threshold value (McMillan, 2003; Sarantis, 2001; Teräsvirta, 2006). The grid search is the standard method in the 
STAR model procedures because the search space of the location parameter is defined to be a function of the transition speed (see Teräsvirta, 1994). In determining the transition variable of the model, all variables are given equal chance of being selected as the transition variable except for the constant and inflation. The results suggest that exchange rate as the transition variable can trigger the nonlinear behaviour in the capital market in Nigeria. This result is underpinned by the large share of foreign investment in the stock market with a value of \$14.44 billion in March 2019.

Table 3: Test for Linearity against Nonlinearity, and LSTAR against ESTAR

\begin{tabular}{|c|c|c|c|c|c|}
\hline Variables & $\mathrm{F}$ & F4 & F3 & $\mathrm{F} 2$ & Remark \\
\hline $\mathrm{Q}(\mathrm{t}-1)$ & $2.46 \mathrm{E}-05$ & $1.11 \mathrm{E}-02$ & $1.26 \mathrm{E}-02$ & $9.94 \mathrm{E}-04$ & LSTAR \\
\hline TBR & $4.40 \mathrm{E}-06$ & 3.19E-01 & $1.19 \mathrm{E}-06$ & 4.19E-03 & ESTAR \\
\hline MPR & $\longrightarrow$ & $\longrightarrow$ & $1.21 \mathrm{E}-01$ & $2.68 \mathrm{E}-05$ & Linear \\
\hline M2 & $7.50 \mathrm{E}-05$ & $3.50 \mathrm{E}-02$ & $2.45 \mathrm{E}-03$ & $6.23 \mathrm{E}-03$ & ESTAR \\
\hline EXR & $1.14 \mathrm{E}-06$ & $4.21 \mathrm{E}-01$ & $4.55 \mathrm{E}-06$ & $5.19 \mathrm{E}-05$ & ESTAR \\
\hline $\operatorname{TBR}(-1)$ & $1.70 \mathrm{E}-03$ & $1.45 \mathrm{E}-01$ & 8.23E-01 & $3.27 \mathrm{E}-06$ & LSTAR \\
\hline $\operatorname{MPR}(-1)$ & - & 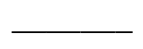 & $1.16 \mathrm{E}-02$ & $5.24 \mathrm{E}-04$ & Linear \\
\hline $\mathrm{M} 2(-1)$ & $5.70 \mathrm{E}-03$ & $3.61 \mathrm{E}-01$ & $3.33 \mathrm{E}-02$ & $2.84 \mathrm{E}-03$ & LSTAR \\
\hline $\operatorname{EXR}(-1) * * *$ & $5.73 \mathrm{E}-09$ & $7.15 \mathrm{E}-03$ & $6.95 \mathrm{E}-06$ & $5.43 \mathrm{E}-05$ & ESTAR \\
\hline Trend & $7.46 \mathrm{E}-03$ & $4.72 \mathrm{E}-01$ & $1.97 \mathrm{E}-01$ & $7.70 \mathrm{E}-05$ & LSTAR \\
\hline
\end{tabular}

Table 4: Results of the ESTAR Model

\begin{tabular}{lllll}
\hline Variables & Linear Coefficient & P-value & Nonlinear Coefficient & P-value \\
\hline Constant & -1130.136 & 0.128 & 1116.96 & 0.1335 \\
Q(-1) & -0.0620 & 0.8935 & 0.9020 & 0.1070 \\
TBR & $-1.1395^{* * *}$ & 0.0003 & $1.116^{* * * *}$ & 0.0005 \\
MPR & -0.9595 & 0.4920 & & \\
M2 & $0.00001^{* * *}$ & 0.0076 & $-0.00002^{* * *}$ & 0.0073 \\
INF & -6.9560 & 0.2219 & 8.559 & 0.1609 \\
EXR & 0.5730 & 0.2744 & -0.8544 & 0.1697 \\
TBR(-1) & $1.3130^{* *}$ & 0.0259 & $-1.3117^{* *}$ & 0.0275 \\
MPR(-1) & $3.7600^{* *}$ & 0.0460 & & \\
M2 $(-1)$ & 0.0000 & 0.8144 & 0.0000 & 0.8496 \\
INF(-1) & 3.6180 & 0.5748 & -5.339 & 0.4328 \\
EXR(-1) & 3.7140 & 0.2966 & -3.4794 & 0.3278 \\
$\gamma$ & & $17.885^{* * *}$ & 0.0055 \\
C1 & & $207.218^{* * *}$ & 0.0000 \\
C2 & & $207.218^{* * *}$ & 0.0000 \\
AIC & & 2.0333 & \\
SIC & & 2.7775 & \\
Adj R2 & & & 0.9761 & \\
\hline Note: $*(* *)^{* * *}$ indicate level of significance at $10 \%(5 \%) 1 \%$ & \\
Source: Authors' computation using jMulti. & & \\
& & & \\
\end{tabular}


The coefficients of the variables in the linear part of the model In Table 4 show that money supply, lagged monetary policy rate and lagged treasury bill rate all have positive significant linkage with the stock market in Nigeria. These have a positive predictive power with the Nigerian stock exchange market during the sample period. Monetary policy is shown to have a direct impact on the stock market where monetary policy rate turns out to be significant for the study with a one-month lag effect. This suggest that the impact of monetary policy rate takes a month before its effect is transmitted to the stock market. On the other hand, the current monetary policy rate (treasury bill rate) is found to have a positive (negative) insignificant effect on the stock market. Both current and lagged monetary policy rate have no asymmetric effect on the stock prices. This negates the discount cash flow model that the monetary policy tightening (easing) is a bad (good) news for the stock market.

For instance, the result shows that money supply has a positive significant effect on the stock market. This effect could be due to the abundant liquidity channelled to investment on the Nigerian stock market. This finding is in line with Osisanwo and Atanda (2012), Afroze (2013), Suhaibu et al. (2017) and Altintas and Yacouba (2018). From Table 4, it is found that treasury bill rate has a positive significant effect on the stock market. The lagged treasury bill rate is shown to have a negative significant impact on the stock market. This suggests that as the short term interest rate increases, investors withdraw their funds from the stock market to invest in risk free assets to get a high expected returns from the open market (Friedman \& Schwartz, 1963; Mishkin, 2016).

The estimates of the nonlinear models are also presented in Table 4. The effect of MPR was omitted due to the finding that the response of stock market to monetary policy rate is linear (Table 3). This points to the fact that monetary policy rate adjustment by the CBN is stable overtime and capable of maintaining a uniform behaviour in the stock market. Whilst the effect of other measures of monetary policy on the stock market transmits to the nonlinear part, the coefficient of treasury bills rate as a measure of short-term interest rate remains positively significant. Money supply is also found to have a negatively significant relationship with the stock exchange market in Nigeria. This implies that an increase in money supply would reduce the stock prices and dampen activities in the stock market. This is in support of Laopodis (2013), that an expansionary monetary policy leads to a fall in stock prices and thus depresses the stock market. Similarly, the lagged treasury bill rate is found to exert a 
negative significant effect on stock prices in this regime as opposed to significant positive effect in the linear regime.

The ESTAR model allows for smooth transition between regimes in stock market behaviour. In the context of stock market, regimes are bull versus bear since in the STAR model contraction and expansion represent two distinct economic phases with a smooth transition (Sarantis, 2001). From Table 4, the constant term is negative (positive) indicating a downward (upward) drift in the stock prices in the lower (upper) regime. The downward (upward) drift in stock prices could be defined to be the bear (bull) market. That is, bull market is a rising market and a rising economy while bear market coincides with falling market prices. The exchange rate among other assets plays a significant role serving as the transition variable in the asymmetric linkage between monetary policy and stock market in Nigeria. The results show that the threshold parameter, $C$ suggests that transition between regimes is determined by the transition variable when it reaches a threshold value of approximately $\$ 207$ which is shown in the lower part of Table 4. The estimated threshold parameters for the STAR model are found to be same for both $C 1$ and $C 2$ with a statistically significant value. The steepness of the transition function determines the speed of the transmission from one regime to the other. The coefficient of the speed of transmission between regimes is found to be rapid with a speed of $18 \%$ within a month. From the linear and nonlinear results, the prevailing idea is that the stock market development can be influenced by monetary policy through different channels in an inconsistent manner. This could be supported by the numerous studies with unclear view on the linkage between monetary policy and stock market for both developed and emerging economies. The results deviate from other studies in Nigeria as it identified the form of regimes in the stock market and which of the variables are significant in the regimes considered. The post estimation results are adequate. The test of autocorrelation results suggests accepting the null hypothesis of no autocorrelation in the errors as seen in Table 5.

Table 5: Test of Autocorrelation

\begin{tabular}{lll}
\hline Lag & F-value & p-value \\
\hline 1 & 0.0602 & 0.4250 \\
2 & 0.6145 & 0.9370 \\
3 & 0.2174 & 0.7820 \\
4 & 0.2567 & 0.8740 \\
\hline
\end{tabular}


Table 6 presents the results for no remaining nonlinearity in the model. The results suggest that the current model is adequate to capture nonlinear dynamics.

Table 6: Test of no remaining nonlinearity

\begin{tabular}{lllll}
\hline Variable & $\mathrm{F}$ & $\mathrm{F} 4$ & $\mathrm{~F} 3$ & $\mathrm{~F} 2$ \\
\hline & $8.79 \mathrm{E}-01$ & $6.23 \mathrm{E}-01$ & $7.07 \mathrm{E}-01$ & $7.96 \mathrm{E}-01$ \\
\hline
\end{tabular}

Finally, Table 7 shows the results for parameter constancy, which indicates that the model is accurate by rejecting the null hypothesis.

Table 7: Parameter Constancy Test

\begin{tabular}{lll}
\hline Transition Function & F-value & p-value \\
\hline H1 & 7.4630 & 0.0000 \\
H2 & 5.9720 & 0.0000 \\
H3 & 4.0160 & 0.0000 \\
\hline
\end{tabular}

The model passed the battery of test of no remaining nonlinearity, autocorrelation, and parameter constancy.

\subsection{Granger Causality Tests}

The results of the STAR based Granger causality tests are shown in Table 8 .

Table 8: Granger Causality Tests

\begin{tabular}{|c|c|c|c|c|}
\hline \multirow[t]{2}{*}{ Hypothesis } & \multicolumn{2}{|c|}{$\begin{array}{l}\text { Linear Granger } \\
\text { causality test }\end{array}$} & \multicolumn{2}{|c|}{$\begin{array}{l}\text { Nonlinear Granger } \\
\text { causality test }\end{array}$} \\
\hline & $\mathrm{F}$ & $\begin{array}{l}\mathrm{p}- \\
\text { value }\end{array}$ & $\mathrm{F}$ & $\begin{array}{l}\mathrm{p}- \\
\text { value }\end{array}$ \\
\hline $\mathrm{Qt} \Leftrightarrow \mathrm{M} 2$ & 10.0401 & 0.0018 & 0.2950 & 0.9670 \\
\hline $\mathrm{M} 2 \Leftrightarrow \mathrm{Qt}$ & 0.6161 & 0.4337 & 743.4620 & 0.0000 \\
\hline $\mathrm{Qt} \Leftrightarrow \mathrm{Mpr}$ & 0.1601 & 0.6896 & 0.0010 & 1.0000 \\
\hline $\mathrm{Mpr} \Leftrightarrow \mathrm{Qt}$ & 3.9876 & 0.0476 & 0.1820 & 0.9930 \\
\hline $\mathrm{Qt} \Leftrightarrow \mathrm{Tbr}$ & 0.0038 & 0.9509 & 0.0260 & 1.0000 \\
\hline $\mathrm{Tbr} \Leftrightarrow \mathrm{Qt}$ & 4.8086 & 0.0298 & 0.2420 & 0.9820 \\
\hline $\mathrm{Qt} \Leftrightarrow \operatorname{Inf}$ & 0.1961 & 0.6585 & -0.0050 & 1.0000 \\
\hline $\mathrm{Inf} \Leftrightarrow \mathrm{Qt}$ & 5.2336 & 0.0235 & 0.3440 & 0.9470 \\
\hline $\mathrm{Qt} \Leftrightarrow \mathrm{Exr}$ & 12.8575 & 0.0004 & -0.0110 & 1.0000 \\
\hline $\mathrm{Exr} \Leftrightarrow \mathrm{Qt}$ & 31.9414 & 0.0000 & 514.9780 & 0.0000 \\
\hline
\end{tabular}

The finding shows linear causality from the stock market to money supply and exchange rate in Nigeria. This is in line with Echekoba et al. (2018) that found a causal effect from stock market to monetary policy decision of the Central Bank of Nigeria (CBN). The result also shows evidence of causality from monetary policy rate and treasury bill rate to the stock market. This implies that the monetary policy decision of the CBN has a direct causal effect 
on the stock market. Inflation was also found to linearly cause the changes in stock market. This supports the finding of Al Mukit and Shafiullah (2012). Furthermore, exchange rate is found to have a causal effect on the stock exchange market performance during the study period. On the other hand, only money supply and exchange rate have nonlinear causal relationship with the stock market. This is related to the finding of Al Mukit and Shafiullah (2012) that showed causality from money supply to stock prices in Dhaka stock market. The results show no causal effect between monetary policy rate, treasury bill rate, inflation and stock prices with the exception of exchange rate.

\subsection{Conclusions and Policy Recommendations}

\subsection{Conclusions}

This paper examined the asymmetric relationship between monetary policy and stock exchange market in Nigeria. From the findings, it is obvious that monetary policy has asymmetric effect on the stock market in different manner. That is, the empirical results from this study show the existence of nonlinear relationship between the monetary policy instruments and the stock market. This points to the significant influence monetary policy has on the stock exchange market in Nigeria. Nonlinearity in the relationship has provided an explanation for the response of the stock market to monetary policy. It revealed the competing directions by identifying the regimes in the stock market. The lower regime was shown to be the bear market indicating a downward drift in the stock prices while the upper regime (bull market) indicates an upward drift in the stock market. The exchange rate has significant role in determining the stock price regime switch from rising price to falling price regime in Nigeria.

\subsection{Policy Recommendations}

The study recommends that the CBN should put in more robust monetary policy easing framework (such as stable money supply) that would continue to translate to stock market performance. This will equally attract foreign portfolio investment in the stock market. The study finds that exchange rate triggers transition in regime in the stock exchange market, this has implication for the participants and the Central Bank as this could be a reflection from foreign portfolio investment. CBN as part of its mandate, should check any excesses inherent in exchange rate market for stability to prevent risk in the stock market behaviour. Stable money supply, monetary policy rate and treasury bill rate should be maintained to drive cap- 
ital market investment that promotes the efficiency and performance in the stock exchange market. An increase in money supply and low monetary policy rate will keep the stock market attractive to both domestic and international investors. This will help to boost investment and achieve greater growth.

\section{References}

Abouwafia, H. E., \& Chambers, M. J. (2015). Monetary policy, exchange rates and stock prices in the Middle East region. International Review of Financial Analysis, 37(C), 14-28. https://doi.org/10.1016/j.irfa.2014.11.001.

Afroze, R. (2013). Impact of monetary policy of Bangladesh bank on the performance of stock market in Bangladesh. ASA University Review, 7, 1-11.

Al Mukit, D. M., \& Shafiullah, A. Z. M. (2012). Impact of monetary policy on post crashed stock market performance: Evidence from Dhaka stock exchange. Journal of Business \& Economics, 4, 106-123.

Altintas, H., \& Yacouba, K. (2018). Asymmetric responses of stock prices to money supply and oil prices shocks in Turkey: New evidence from a nonlinear ARDL approach. International Journal of Economics and Financial Issues, 8, 45-53.

Arango, L. E., González, A., \& Posada, C. E. (2002). Returns and the interest rate: A non-linear relationship in the Bogotá stock market. Applied Financial Economics, 12, 835-842. https://doi.org/10.1080/09603100110094493.

Aslanidis, N., Osborn, D. R., \& Sensier, M. (2002). Smooth transition regression models in UK stock returns. University of Manchester, Mimeo.

Belke, A., \& Beckmann, J. (2015). Monetary policy and stock prices - Cross-country evidence from cointegrated VAR models. Journal of Banking and Finance, 54(C), 254265. https://doi.org/10.1016/j.jbankfin.2014.12.004.

Bertram, O. A. (2018). Economic growth and capital market development in Nigeria; An appraisal. Journal of Business Management and Economic Research, 2, 27-38. https://doi.org/10.29226/tr1001.2018.28.

Bjørnland, H. C., \& Leitemo, K. (2009). Identifying the interdependence between US monetary policy and the stock market. Journal of Monetary Economics, 56, 275-282. https://doi.org/10.1016/j.jmoneco.2008.12.001.

Cevik, E. I., Dibooglu, S., \& Kutan, A. M. (2014). Monetary And fiscal policy interactions: Evidence from emerging European economies. Journal of Comparative Economics, 42, 1079-1091. 
Chatziantoniou, I., Duffy, D., \& Filis, G. (2013). Stock market response to monetary and fiscal policy shocks: Multi-country evidence. Economic Modelling, 30(C), 754-769. https://doi.org/10.1016/j.econmod.2012.10.005.

Chude, N. P., \& Chude, D. I. (2013). Effect of money supply on the stock market returns in Nigeria. Journal of Business and Organizational Development, 5, 135-150.

Echekoba, F., Ananwude, A., \& Lateef, O. (2018). Effect of monetary policy on the performance of the Nigerian capital market $(1986$ - 2016): Stylized facts from ARDL approach. Advances in Research, 14, 1-15.

Echekoba, F., Okaro, C. S. O., Ananwude, A., \& Akuesodo, O. E. (2017). Monetary policy and capital market performance: An empirical evidence from Nigerian data. Research Journal of Economics, 1, 1-5.

Erer, D., \& Gacener-Atis, A. (2018). The impact of monetary policy on stock returns during bull and bear markets: the evidence from Turkey. Ege Akademik Bakis (Ege Academic Review), 18, 699-710. https://doi.org/10.21121/eab.2018443010.

Friedman, M., \& Schwartz, A. J. (1963). A monetary history of the United States, 18671960. In A Monetary History of the United States, 1867-1960. https://doi.org/10.2307/2550627.

Handoyo, R., Jusoh, M., \& Zaidi, M. (2015). Impact of monetary policy and fiscal policy on Indonesian stock market. Expert Journal of Economics, 3, 113-126.

Hyde, S., \& Bredin, D. (2011). Regime changes in the relationship between stock returns and the macroeconomy. SSRN Electronic Journal. https://doi.org/10.2139/ssrn.686878.

Ifionu, E. P., \& Omojefe, G. . (2013). The capital market and performance of the Nigerian economy: A time series analysis.West African Journal of Industrial and Academic Research, 8, 192-207.

Ioannidis, C., \& Kontonikas, A. (2008). The impact of monetary policy on stock prices. Journal of Policy Modeling, 30, 33-53. https://doi.org/10.1016/j.jpolmod.2007.06.015.

Jansen, D. W., \& Tsai, C. L. (2010). Monetary policy and stock returns: Financing constraints and asymmetries in bull and bear markets. Journal of Empirical Finance, 17, 981-990. https://doi.org/10.1016/j.jempfin.2010.08.002.

Laopodis, N. T. (2013). Monetary policy and stock market dynamics across monetary regimes. Journal of International Money and Finance, 33(C), 381-406. https://doi.org/10.1016/j.jimonfin.2012.09.004. 
Ma, Y. (2016). Nonlinear monetary policy and macroeconomic stabilization in emerging market economies: Evidence from China. Economic Systems, 40, 461-480. https://doi.org/http://dx.doi.org/10.1016/j.ecosys.2015.12.003.

McMillan, D. G. (2001). Nonlinear predictability of stock market returns: Evidence from nonparametric and threshold models. International Review of Economics and Finance, 10, 353-368. https://doi.org/10.1016/S1059-056000093-4.

McMillan, D. G. (2003). Non-linear predictability of UK stock market returns. Oxford Bulletin of Economics and Statistics, 65, 557-573. https://doi.org/10.1111/j.14680084.2003.00061.

Mishkin, F. S. (2016). The economics of money, banking, and financial markets. In Pearson Education Limited.

Muktadir-Al-Mukit, D., \& Shafiullah, A. (2012). Impact of monetary policy on post crashed stock market performance: Evidence from Dhaka stock exchange. Journal of Business \& Economics, 4, 106-123.

Nwakoby, C. In. kechukwu, \& Alajekwe, B. U. (2016). Effect of monetary policy on Nigerian stock market performance. International Journal of Scientific Research \& Management Studies, 4, 4530-4442.

Okpara, G. (2010). Monetary policy and stock market returns: Evidence from Nigeria. Journal of Economics, 1, 13-21.

Ologunde, A. O., Elumilade, D. O., \& Asaolu, T. O. (2006). Stock market capitalization and interest rate in Nigeria: A time series analysis. International Research Journal of Finance and Economics, 4, 154-166.

Osisanwo, B. G., \& Atanda, A. A. (2012). Determinants of stock market returns in Nigeria : A time series analysis. African Journal of Scientific Research, 9, 3-23.

Petersen, K. (2007). Does the federal reserve follow a non-linear Taylor rule? Economics Working Papers, 1-19.

Pilinkus, D. (2010). Macroeconomic indicators and their impact on stock market performance in the short and long run: The case of the baltic states. Technological and Economic Development of Economy, 16, 291-304. https://doi.org/10.3846/tede.2010.19.

Sarantis, N. (2001). Nonlinearities, cyclical behavior and predictability in stock markets: International evidence. International Journal of Forecasting, 17, 459-482. https://doi.org/DOI: 10.1016/S0169-20700100093-0.

Singh, B., \& Nadkarni, A. R. (2020). Role of credit and monetary policy in determining asset prices: Evidence from emerging market economies. North American Journal of Economics and Finance, 51(C). https://doi.org/10.1016/j.najef.2018.11.003. 
Suhaibu, I., Harvey, S. K., \& Amidu, M. (2017). The impact of monetary policy on stock market performance: Evidence from twelve African countries. Research in International Business and Finance, 42(C), 1372-1382.

Tang, Y., Luo, Y., Xiong, J., Zhao, F., \& Zhang, Y. C. (2013). Impact of monetary policy changes on the Chinese monetary and stock markets. Physica A: Statistical Mechanics and Its Applications, 392, 4435-4449. https://doi.org/10.1016/j.physa.2013.05.023

Teräsvirta, T. (1994). Specification, estimation, and evaluation of smooth transition autoregressive models. Journal of the American Statistical Association, 89425, 208-218. https://doi.org/10.1080/01621459.1994.10476462

Teräsvirta, T. (1998). Modelling economic relationships with smooth transition regression. In Handbook of Applied Economic Statistics.

Teräsvirta, T. (2004). Smooth transition regression modeling. In Applied Time Series Econometrics. https://doi.org/10.1017/CBO9780511606885.007

Teräsvirta, T. (2006). Forecasting economic variables with nonlinear models. Handbook of Economic Forecasting. https://doi.org/10.1016/S1574-07060501008-6

Teräsvirta, T., \& Anderson, H. (1992). Characterizing nonlinearities in business cycles using smooth transition autoregressive models. Journal of Applied Econometrics, 71, 119-136.

Thorbecke, W. (1997). On stock market returns and monetary policy. Journal of Finance, $522,635-654$.

https://doi.org/10.1111/j.1540-6261.1997.tb04816.x

Tumala, M. M., \& Yaya, O. S. (2015). Estimating bull and bear betas for the Nigerian stock market using logistic smooth threshold model. CBN Journal of Applied Statistics, 061, 263-284. Retrieved from http://hdl.handle.net/10419/142098

Umezurike, C. M., \& Ananwude, A. (2019). Impact of Monetary Policy on Value of Stock Traded: Short Run and Long Run Evidence from Nigerian Stock Exchange (19872017). Asian Journal of Advanced Research and Reports, 5, 1-9. 